\title{
Optimum dietary level of Chlorella vulgaris powder as a feed additive for some blood parameters and digestive enzymatic activities of grey mullet, Mugil cephalus
}

\author{
Akbary P* and Malek Raeisi E \\ Chabahar Maritime University, Iran \\ Submission: December 12, 2017; Published: June 18, 2018 \\ Corresponding author: Paria Akbary, Faculty of Marine Sciences, Fisheries group, Chabahar Maritime University, Chabahar, Iran; \\ Tel: +985431272340; Fax: +985435324513; Email: paria.akbary@gmail.com
}

\begin{abstract}
The present paper aims to shed lights on effect of optimum dietary level of Chlorella vulgaris powder (CP) as a feed additive on some blood biochemical parameters (Cholesterol (CHO), triglyceride (TG), total protein (TP), glucose (GLU), glutamic oxaloacetic transaminase (GOT), glutamic pyruvic transaminase (GPT) and lysozyme) and digestive enzymatic activities (amylase, lipase and protease) of the grey mullet (Mugil cephalus L). Four experimental diets were supplemented with CP at 0, 5, 10 and $15 \mathrm{~g} \mathrm{~kg}^{-1}$ diet (CP0, CP, CP10 and CP15). Number of twelve tanks (60L) with three replicates for treatment group $(\mathrm{n}=10$ per tank with average initial weights $14.95 \pm 2.01 \mathrm{~g})$ and the control group were considered. After 60 days of the feeding trial, fish fed CP5 diet had lower serum CHO and TG levels than did fish fed CP0, CP10 and CP15 diets (P<0.05). There was no significant difference in GLU between fish fed CP5 and CP10 diet ( $>>0.05)$. The highest serum total protein, amylase, protease, lipase and lysozyme activities were observed in fish fed CP5. Also, fish fed CP10 and CP15 diets had higher digestive enzymatic activities, serum total protein and lysozyme activities than did fish fed CP0 $(\mathrm{P}<0.05)$. These results indicate that dietary supplementation of $5 \mathrm{~g}$ chlorella powder in the commercial diets could improve the blood chemical responses and the activity of digestive enzyme in grey mullet.
\end{abstract}

Keywords: Mugil cephalus; Chlorella vulgaris; Additive digestive enzymes; Blood biochemical parameters

\section{Introduction}

Successful rearing of larval fish is the most critical stage in the production cycle for many species. Mugil cephalus has a promising market potential in Europe, East and South Asia [1]. It is also an important aquaculture species in Iran. The consumer demand stimulated the development of intensive aquaculture of this species in Asian countries. The problem in rearing larval fish is that of food supply [2]. Therefore a readily available, easily acceptable and highly digestible diet with high nutritional value should be used as larval fish starter diet $[3,4]$.

Plants are natural sources of safer and cheaper chemicals. Plant products have been reported to promote various activities like anti stress, growth promotion, appetite stimulation and immunostimulation in aquaculture practices $[5,6]$.

Chlorella sp. as one of the most common microalgae used in aquaculture, have been reported to improve lipid metabolism, digestive enzymatic activities, growth, feed utilization in Korean rockfish, Sebastes schlegeli [7], juvenile Japanese flounder, Paralichthys olivaceus [8], gibel carp, Carassius auratus gibelio [9,10], olive flounder, Paralichthys olivaceus [11].
Freshwater algae such as Chlorella and Spirulina seem to have good potential as protein sources, whereas marine microalgae are the fundamental source of the long-chain polyunsaturated fatty acids that are crucial for human health, as well as that of aquaculture animals. Chlorella vulgaris shows some potential as an alternative feed ingredient in aquaculture due to its richness in protein, polysaccharides, vitamins and microelements [9]. Although the algal feeds were not utilized as efficiently as the fishmeal feed, Chlorella was well accepted. As example Shi et al. [10] showed that Chlorella meal could totally replace dish meal in diet of crucian carp, C. auratus.

Until now, no trial has been conducted to study the effect of dietary Chlorella powder on some of serum biochemical parameters and digestive enzymatic activities of grey mullet. This study was therefore designed to investigate effect of optimum dietary level of Chlorella vulgaris powder (CP) as a feed additive on some blood biochemical parameters (Cholesterol (CHO), triglyceride (TG), total protein (TP), glucose (GLU), glutamic oxaloacetic transaminase (GOT), glutamic pyruvic transaminase 
(GPT) and lysozyme) and digestive enzymatic activities (amylase, lipase and protease) of the grey mullet.

\section{Materials and Methods}

\section{Experimental diets and feeding conditions}

Chlorella vulgaris powder were purchased from the Yakhteh Nano-chemistry Co in Tehran, Four diets were prepared with supplementation of Chlorella powder (CP) at inclusion level of $0,5,10$ and $15 \mathrm{~g} \mathrm{~kg}^{-1}$ diet, analyzed proximate compositions are presented in Table 1. After mixing well with ingredients, oil and $30 \%$ distilled water were added and further mixed. The wet dough was pelletized at a particle size of $1 \mathrm{~mm}$ using a chopper machine (National, Japan). The experimental diets were freezedried, sieved into the desired particle size $(1 \mathrm{~mm})$ and then stored at $-4-8{ }^{\circ} \mathrm{C}$ until use [12].

Table 1: Ingredients $\left(\mathrm{g} \mathrm{kg}^{-1}\right)$ and chemical composition (\%) of the experimental diets.

\begin{tabular}{|c|c|c|c|c|}
\hline \multirow{2}{*}{ Ingredients ( $\mathrm{g} \mathrm{kg}^{-1}$ ) } & \multicolumn{4}{|c|}{ Diets } \\
\hline & CPO & CP5 & CP10 & CP15 \\
\hline Chlorella vulgaris $\left(\mathrm{g} \mathrm{kg}^{-1}\right)$ & 0 & 5 & 10 & 15 \\
\hline Fish meal & 427 & 427 & 427 & 427 \\
\hline Soybean meal & 192.5 & 192.5 & 192.5 & 192.5 \\
\hline Wheat flour & 93 & 93 & 93 & 93 \\
\hline Dried yeast & 37.5 & 37.5 & 37.5 & 37.5 \\
\hline Fish oil & 55 & 55 & 55 & 55 \\
\hline Soy oil & 27.5 & 27.5 & 27.5 & 27.5 \\
\hline Choline chloride & 2 & 2 & 2 & 2 \\
\hline Bi calcium phosphate & 3.7 & 3.7 & 3.7 & 3.7 \\
\hline Lecithin & 28.15 & 28.15 & 28.15 & 28.15 \\
\hline Premix $^{\mathrm{a}}$ & 9.4 & 9.4 & 9.4 & 9.4 \\
\hline \multicolumn{5}{|c|}{ Proximate composition (\%) } \\
\hline Crude protein & 51.6 & 51 & 50.6 & 51.6 \\
\hline Crude lipid & 11.9 & 11 & 11.4 & 11.2 \\
\hline Crude ash & 12.1 & 12 & 11.8 & 12.6 \\
\hline Dry matter & 92.2 & 92.1 & 92 & 92 \\
\hline
\end{tabular}

aPremix $\left(\mathrm{mg} \mathrm{kg}^{-1}\right) \mathrm{KI}, 250 ; \mathrm{MnSO}_{4} \cdot \mathrm{H}_{2} \mathrm{O}, 2800 ; \mathrm{ZnSO}_{4} \cdot \mathrm{H}_{2} \mathrm{O}, 2350$; vitamin $\mathrm{K}, 225$; biotin $3500,(2 \%)$ niacin, 4850; calcium pantothenate, 11,000 ; folic acid, 2000; vitamin $B_{1}, 1500$; vitamin $B_{2}, 2000$; vitamin $B_{6}, 2000$; and vitamin $C, 50,000$.

The feeding experiment was conducted at Fisheries Research Center, Chabahar, Iran. one hundred- twenty grey mullet with an initial mean weight of $14.95 \mathrm{~g}$ were randomly distributed into twelve tanks (60L) at a stocking density of $10 \mathrm{fish} / \mathrm{tank}$ (triplicates per treatment) and fed to satiation by hand twice (09:00 and 17:00) a day for 60 days and feed intake was recorded on daily basis. Dissolved oxygen concentration, ammonia nitrogen concentration and $\mathrm{pH}$ were measured about $7.01 \pm 0.87 \mathrm{mg} \mathrm{L}^{-1}$, $0.11 \pm 0.04 \mathrm{mg} \mathrm{L}^{-1}$ and $7.8 \pm 0.4$ respectively. The photoperiod was regulated as a $12: 12 \mathrm{~h}$ (dark/light) cycle.

\section{Biochemical analysis}

At the end of experiment, number of nine fish from each treatment were anesthetized (with clove oil at $5 \mathrm{mg} \mathrm{L}^{-1}$ ) and blood samples were taken after excising caudal peduncle and were transferred to un-heparinized sterile tubes $1-1.5 \mathrm{~mL}$ for the serum biochemical tests proposes [2,13].

Serum glucose concentration was measured according to method described By Trinder [14]. Serum total protein was determined via the method described by Wootton [15]. Triglyceride and cholesterol level determination was carried out according to the method described by Sankar [16]. Biochemical estimation of blood glucose, protein, cholesterol and triglyceride were determined by means of standard analyses kits (Pars Azmon, Iran) using automatic analyzer (Furuno, CA-270, Japan).

The turbidimetric assay for lysozyme was carried out with minor modification [17]. In brief, substrate for the assay of lysozyme was performed using $0.03 \%$ of lyophilized cells of Micrococcus lysodeikticus (Sigma, ATCC No. 4698) in $0.05 \mathrm{mM}$ sodium phosphate buffer ( $\mathrm{pH}$ 6.2). Twenty-five microliters of fish plasma were added to $175 \mu$ bacterial suspensions in duplicate wells of a microtitre plate. The mixture was incubated at room temperature and an absorbance at $600 \mathrm{~nm}$ was measured after $15 \mathrm{~s}$ using an ELISA plate reader (Argus, Perkin Elmer, France). A unit of lysozyme activity was defined as a plasma-decrease amount of lysozyme in absorbance of $0.001 \mathrm{~mL}^{-1} \mathrm{~min}^{-1}$.

\section{Digestive enzyme activity}

For preparation of enzyme extracts, three fish from each tank were randomly selected and sacrificed. The digestive tracts were carefully dissected out, thoroughly washed with sterile distilled water, weighed and separately homogenized with cooled buffer 
phosphate $(0.65 \%, \mathrm{pH} 7,1: 10 \mathrm{w} / \mathrm{v})$. The supernatant, extracted by centrifugation $\left(3000 \mathrm{~g}\right.$ for $20 \mathrm{~min}$ at $4{ }^{\circ} \mathrm{C}$ ) (Centrifuge EBA21, Hettich, Germany), was used for enzyme assays. Amylase activity was assessed by 3, 5- dinitrosalicylic acid (DNS) method (King, 1965). $0.1 \mathrm{ml}$ tissue homogenate, $2 \mathrm{ml}$ phosphate buffer $(0.1 \mathrm{M}, \mathrm{pH}$ 7) and $0.1 \mathrm{ml}$ of $1 \%(\mathrm{w} / \mathrm{v})$ starch solution was mixed and incubated at $30{ }^{\circ} \mathrm{C}$ for $35 \mathrm{~min}$. Then adding $2 \mathrm{ml}$ DNS reagent stopped the reaction. After $5 \mathrm{~min}$ in boiling water, the reaction mixture was cooled, diluted with distilled water and recorded the absorbance at $540 \mathrm{~nm}$. Protease activity was measured by the casein digestion method of king (1965). $0.1 \mathrm{ml}$ tissue homogenated, $0.05 \mathrm{M}$ tris phosphate buffer (PH 7.8), $0.01 \mathrm{~N} \mathrm{NaOH}$ and $2.5 \mathrm{ml}$ of $1 \%(\mathrm{w} / \mathrm{v}$ ) consisted the reaction mixture. The mixture was incubated at $30{ }^{\circ} \mathrm{C}$ for $10 \mathrm{~min}$ and stopped by $2.5 \mathrm{ml}, 10 \%$ trichloroacetic acid (TCA) and filtered. The reagent blank consisted just tissue homogenate before stopping the reaction and without incubation. The absorbance was recorded at 320nm. Unit amylase activity was calculated as the weight ( $\mathrm{mg}$ ) of maltose liberated for a duration of $10 \mathrm{~min}$ at $30{ }^{\circ} \mathrm{C}$. Unit protease activity was expressed as the amount of tyrosine liberated in $15 \mathrm{~min}$ under the assay conditions. Lipase activity was assessed by King method. Olive oil emulsion, phosphate buffer ( $\mathrm{pH} 7.8,0.1 \mathrm{M})$, tissue homogenate and distilled water consisted the reaction mixture. The reaction mixture was incubated at $30{ }^{\circ} \mathrm{C}$ for $24 \mathrm{~h}$ and added two drops phenolphthalein indicator and $95 \%$ alcohol for titration against $0.05 \mathrm{~N} \mathrm{NaOH}$ until the appearance of permanent pink color. Unit lipase activity expressed as the amount of $0.025 \mathrm{~N} \mathrm{NaoH}$ required to neutralize the fatty acids liberated during $18 \mathrm{~h}$ of incubation at $\mathrm{pH} 6.9$ and temperature $30^{\circ} \mathrm{C}$. Digestive enzymes were calculated as enzyme unit per gram tissue.

\section{Statistical analysis}

All measurements were repeated twice. Data were evaluated using one- way analysis of variance (ANOVA). Groups were considered to be significantly different if $\mathrm{P}<0.05$. When a significant $\mathrm{F}$ value was obtained for ANOVA the differences between all groups were tested by using Duncan multiple comparisons test. All statistics were performed using SPSS for windows versions 16. Data are reported as means \pm standard Error.

\section{Results}

\section{Effect of Chlorella powder (CP) on the blood biochemical parameters of grey mullet}

The blood parameters of fish fed with the experimental diets were shown in Table 2. Analysis of the data in Table 2 suggested that the dietary chlorella mainly affected the parameters involved in protein/ lipid metabolism and immunity of grey mullet. The serum total protein content and lysozyme activity were significantly $(\mathrm{p}<0.05)$ increased for fish fed CP diet over the control. The highest total protein content was recorded in those fish fed CP5 diet. There was significant $(\mathrm{p}<0.05)$ decline in cholesterol, glucose and triglycerides levels in those fish fed CP diet over the control (Table 1). The lowest cholesterol, glucose and triglycerides levels of serum were observed in fish fed CP5.

Table 2: Serum biochemical parameters of M.cephalus fed CP diet at different levels for 60 days.

\begin{tabular}{|c|c|c|c|c|}
\hline \multirow{2}{*}{ Parameter } & \multicolumn{4}{|c|}{ CP diet (g kg $\mathbf{~ f e e d})^{-1}$} \\
\cline { 2 - 5 } & $\mathbf{0}$ & $\mathbf{5}$ & $\mathbf{1 0}$ & $\mathbf{1 5}$ \\
\hline Total protein (g dl-1) & $4.42 \pm 0.43^{\mathrm{d}}$ & $6.58 \pm 0.33^{\mathrm{a}}$ & $5.45 \pm 0.21^{\mathrm{b}}$ & $3.97 \pm 0.18^{\mathrm{c}}$ \\
\hline Glucose (mg dl-1) & $55 \pm 1.52^{\mathrm{a}}$ & $31 \pm 11.52^{\mathrm{c}}$ & $35.33 \pm 10.45^{\mathrm{bc}}$ & $37 \pm 11.33^{\mathrm{b}}$ \\
\hline Triglycerides (mg dl-1) & $227.33 \pm 11.76^{\mathrm{a}}$ & $172 \pm 10.05^{\mathrm{d}}$ & $191 \pm 12.64^{\mathrm{c}}$ & $209.28 \pm 14.75^{\mathrm{b}}$ \\
\hline Cholesterol (mg dl-1) & $104.79 \pm 10.76^{\mathrm{a}}$ & $75.33 \pm 13.7^{\mathrm{c}}$ & $95 \pm 11.73^{\mathrm{b}}$ & $100 \pm 11.15^{\mathrm{b}}$ \\
\hline Lysozyme & $149 \pm 15.53^{\mathrm{c}}$ & $275.07 \pm 18.45^{\mathrm{a}}$ & $199.67 \pm 10.88^{\mathrm{b}}$ & $185 \pm 12.88^{\mathrm{b}}$ \\
\hline
\end{tabular}

CP diet, Chlorella powder diet. Values (mean \pm SE of three replication). In each row not sharing a common superscript are significantly different $(\mathrm{P}<0.05)$.

\section{Effect of Chlorella powder (CP) on the digestive enzymatic activities of grey mullet}

The activity of three digestive enzymes including amylase, lipase and protease in intestine were examined, and the results were summarized in Table 3. These three enzymes were significantly increased for fish fed CP diet compared with control. The highest the digestive enzymatic activities were recorded in those fish fed CP5 diet. However there was no significant changes in the activity of these three enzymes among fish fed CP10 diet and $\mathrm{CP} 15$ diet $(\mathrm{P}>0.05)$.

Table 3: Digestive enzyme activities of $M$. cephalus fed CP diet at different levels for 60 days.

\begin{tabular}{|c|c|c|c|c|}
\hline \multirow{2}{*}{$\begin{array}{c}\text { Specific activity of enzyme } \\
\text { (unit mg-1 protein) }\end{array}$} & \multicolumn{4}{|c|}{ CP diet $\mathbf{~ ( g ~ k g}^{-1}$ feed) } \\
\cline { 2 - 5 } & $\mathbf{0}$ & $\mathbf{5}$ & $\mathbf{1 0}$ & $\mathbf{1 5}$ \\
\hline Amylase & $26.3 \pm 8.92^{\mathrm{c}}$ & $45.66 \pm 11.45^{\mathrm{a}}$ & $34.33 \pm 9.32^{\mathrm{b}}$ & $36 \pm 12.08^{\mathrm{b}}$ \\
\hline Protease & $356.67 \pm 23.07^{\mathrm{c}}$ & $520 \pm 11.73^{\mathrm{a}}$ & $450 \pm 15^{\mathrm{b}}$ & $432 \pm 14.93^{\mathrm{b}}$ \\
\hline Lipase & $211 \pm 10.21^{\mathrm{b}}$ & $514 \pm 11.58^{\mathrm{a}}$ & $406.67 \pm 17.67^{\mathrm{b}}$ & $378.67 \pm 16.90^{\mathrm{b}}$ \\
\hline
\end{tabular}

$\mathrm{Cp}$ diet, Chlorella powder diet. Values (mean $\pm \mathrm{SE}$ of three replication).In each row not sharing a common superscript are significantly different $(\mathrm{P}<0.05)$. 


\section{Discussion}

In the present study, the different contents of Chlorella powder were added in the basal diet of grey mullet and the effects of Chlorella on the blood biochemical parameters and digestive enzyme were detected.

5-15g Chlorella powder in diets could significantly improve the blood parameters of grey mullet. In this study, significantly lower serum total cholesterol concentrations were detected in all levels of CP in comparison to those fed the control diet. In agreement with our results, Rahimnejad \& Lee [11] reported the significant reduction of serum cholesterol level in olive flounder, Paralichthys olivaceus fed diets containing 5-15\% C. vulgaris. Also $\mathrm{Xu}$ et al. [9] found the significant decrease of serum cholesterol level in gibel carp fed diets supplemented with 1.6-2\% Chlorella powder. Similar tendency of decreasing blood cholesterol level also been achieved in olive flounder fed diets containing $2-4 \% C$. ellpsoidea [8], suggesting that Chlorella supplementation could activate hormonal regulation of lipid metabolism [9]. In this study, significantly higher serum total protein concentrations and lysozyme activity were detected in all levels of CP in comparison to those fed the control diet. Similar tendency of increasing the serum total protein and lysozyme activity also been achieved in olive flounder fed diets containing 2-4\% C. ellpsoidea and in gibel carp fed 1.6-2\% Chlorella powder. Protein and lysozyme play important roles in the immune system $[9,18]$. Our findings suggested that the dietary adding Chlorella could increase the immune response of grey mullet. Lysozyme is also an important defense molecule of the innate immune system, which is important in mediating protection against microbial invasion [18]. Increasing lysozyme and total protein by dietary Chlorella suggested that the Chlorella might contain some bioactive substances involving in the regulating of fish immune response.

In this study, significantly lower triglyceride and glucose levels were detected in all levels of CP in comparison to those fed the control diet, suggesting that the chlorella might involve in the metabolism of carbohydrate. Conversely, Xu et al. [9] showed that Chlorella powder could decrease the level of blood cholesterol not the glucose of gibel carp. The same case also found by Güroy et al. [19], suggesting that its effect also variably depend on dietary Chlorella species and its concentrations [8].

The results of the present study indicated that using the different levels $C$. vulgaris powder play a positive role on the activity of digestive enzymes. Analysis of digestive enzyme activity is an easy and reliable methodology that can be used as an indicator of digestive processes and nutritional condition of fish [20]. M. cephalus is a stomatch- less fish. Digestion takes place in the intestine, in which various intestinal enzymes are involved in digestive and absorptive processes, such as amylase, protease, lipase [21]. Similar positive observations were reported by $\mathrm{Xu}$ et al. [9] with increasing the digestive enzyme in the hepatopancreas and intestine in gibel carp, Carassius auratus gibelio fed with Chlorella, suggesting the Chlorella could enhance the diet utilization rate by increasing the activity of digestive enzyme. Also, Shi et al. [10] showed that dietary Chlorella meal substitution could significantly increase the activities of amylase but not activities of trypsin and lipase in intestine of crucian carp, Carassius auratus. Increased amylase activities may improve the utilization of carbohydrates in diets. Vizcaino et al. [22] reported that algae inclusion could significantly increase the activities of trypsin but not activities of trypsin of sea bream, Sparus aurata. In this study, the highest digestive enzyme activities were observed in fish fed with CP5, while the activity of these three enzyme in gibel carp fed with $2 \%$ Chlorella group were the higher than those of other groups. Suggesting the optimum level of dietary microalga on digestive enzymatic activities was variable even in conspecific [9]. Information about suitable concentration of dietary microalga that beneficially affects fish digestive enzymes might be required for application in aquafeed.

\section{Conclusion}

In conclusion, the present study revealed that dietary supplementation of $5 \mathrm{~g} \mathrm{C}$. vulgaris powder in each $\mathrm{kg}$ diet, as a feed additive, improved biochemical parameters and digestive enzymatic activities in grey mullet. Therefore, this study suggests that optimum dietary supplementation level of Chlorella powder could be approximately $5 \mathrm{~g} \mathrm{~kg}^{-1}$ of diet for the positive effects on blood biochemical parameters and digestive enzymatic activities in grey mullet.

\section{Acknowledgment}

We would like to thank the personnel of the Fisheries Researches Center, Chabahar, Iran. Special thanks are due to Dr N Tayari Sadaf laboratory expert, Chabahar, Iran, for her valued efforts.

\section{References}

1. Yelghi S, Shirangi SA, Ghorbani R, Khoshbavar Rostami HA (2012) Annual cycle of ovarian development and sex hormones of grey mullet (Mugil cephalus) in captivity. Iranian Journal of Fisheries Sciences 11(3): 693-703.

2. Akbary P, Pirbeigi A, Jahanbakhshi A (2016) Analysis of primary and secondary stress responses in bighead carp (Hypophthalmichthys nobilis) by anesthetization with 2- phenoxyethanol. International Journal of Environmental Science and Technology 13(4): 1009-1016.

3. Girri SS, Sahoo SK, SHU BB, Sahu AH, Mohanty SN, et al. (2002) Larval survival and growth in Wallago attu (Bloch and Schneider): effects of light photoperiod and feeding regims. Aquaculture 213(1-4): 157-161.

4. Akbary P, Hosseini SA, Imanpoor MR (2011) Enrichment of Artemia nauplii with essential fatty acids and vitamin $\mathrm{C}$ : effect on rainbow trout (Oncorhynchus mykiss) larvae performance. Iranian Journal of Fisheries Sciences 10(4): 557-569.

5. Citarasu T, Sekar RR, Babu MM, Marian MP (2002) Developing Artemia enriched herbal diet for producing quality larvae in Penaeus monodon. Asian Fisheries Science 15(1): 21-32.

6. Sivaram V, Babu MM, Citarasu T, Immanuel G, Murugadass S, et al. (2004) Growth and immune response of juvenile greasy groupers (Epinephelus tauvina) fed with herbal antibacterial active principle supplemented diets against Vibrio harveyi infections. Aquaculture 237(1-4): 9-20. 
7. Bai SC, Koo JW, Kim KW, Kim SK (2001) Effects of Chlorella powder as a feed additive on growth performance in juvenile Korean rockfish, Sebastes schlegeli (Hilgendorf). Aquaculture Research 32(S1): 92-98.

8. Kim KW, Bai SC, Koo JW, Wang X (2002) Effects of dietary Chlorella ellipsoidea supplementation on growth, blood characteristics, and whole body composition in juvenile Japanese flounder Paralichthys olivaceus. Journal of the World Aquaculture Society 33(4): 425-431.

9. Xu W, Gao Z, Qi ZT, Qiu M, Peng JQ et al. (2014) Effect of dietary chlorella in the growth performance and physiological parameters of gibel carp, Carassius auratus gibelio. Turkish Journal of Fisheries and Aquatic Sciences 14: 53-57.

10. Shi X, Luo Z, Chen F, Huang C, Zhu XM, et al. (2016) Effect of fish meal replacement by Chlorella meal with dietary cellulase addition on growth performance, digestive enzymatic activities, histology and myogenic genes' expression for crucian carp Carassius auratus. Aquaculture Research 48(6): 3244-3256.

11. Rahimnejad S, Lee SM (2017) Effects of Dietary Inclusion of Chlorella vulgaris on Growth, Blood Biochemical Parameters, and Antioxidant Enzyme Activity in Olive Flounder, Paralichthys olivaceus. Journal of the world aquaculture society 48(1): 103-112.

12. Choi YH, Lee BJ, Nam TJ (2015) Effect of dietary inclusion of Pyropia yezoensis extract on biochemical and immune responses of olive flounder Paralichthys olivaceus. Aquaculture 435: 347-353.

13. Shaluei F, Hedayati A, Jahanbakhshi A, Baghfalaki M (2012) Physiological responses of great sturgeon (Huso huso) to different concentrations of 2-phenoxyethanol as an anesthetic. Fish Physiol Biochem 38(6): 1627-1634.

14. Trinder P (1969) Determination of glucose in blood using glucose oxidase with an alternative oxygen acceptor. Annals of Clinical Biochemistry 6(1): 24-27.
15. Wootton LI (1964) Micro-analysis in medical biochemistry in micrometer, (4 ${ }^{\text {th }}$ edn), J \&A Churchill, London, UK, England, pp. 264.

16.Sankar G, Elavarasi A, Sakkaravarthi K, Ramamoorthy K (2011) Biochemical changes and growth performance of black tigher shrimp larvae after using Ricinus communis extract as feed additive. International Journal of Pharm Tech Research 3(1): 201-208.

17. Ellis AE (1990) Lysozyme Assays. In: Stolen JS, Fletcher TC, Anderson DP, Roberson BS, Van Muiswinkel WB, (Eds.), Techniques in: Fish Immunology. SOS Publications, Fair Haven, New Jersy, USA, pp. 101103.

18. Kumar S, Raman RP, Kumar K, Pandey PK, Kumar N, et al. (2012) Effect of azadirachtin on haematological and biochemical parameters of Argulus-infected goldfish Carassius auratus (Linn. 1758). Fish Physiol Biochem 39(4): 733-747.

19. Güroy D, Güroy B, Merrifield DL, Ergün S, Tekina AA et al. (2011) Effect of dietary Ulva and Spirulina on weight loss and body composition of rainbow trout, Oncorhynchus mykiss (Walbaum), during a starvation period. J Anim Physiol Anim Nutr (Berl) 95(3): 320-327.

20. Abolfathis M, Hajimoradloo A, Ghorbani R, Zamani A (2012) Effect of starvation and refeeding on digestive enzyme activities in juvenile roach, Rutilus rutilus caspicus. Comp Biochem Physiol A Mol Integr Physiol 161(2): 166-173.

21. Das KM, Tripathi SD (1991) Studies on the digestive enzymes of grass carp, Ctenopharyngodon idella (Val). Aquaculture 92: 21-32.

22. Vizcaĺnno A, Lopez G, Sáaez M, Jimènez J, Barros A, et al. (2014) Effects of the microalga Scenedesmus almeriensisas fishmeal alternative in diets for gilthead sea bream, Sparus aurata, juveniles. Aquaculture 431: 34-43.

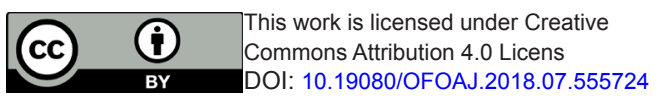

\begin{tabular}{l} 
Your next submission with Juniper Publishers \\
will reach you the below assets \\
- Quality Editorial service \\
- Swift Peer Review \\
- Reprints availability \\
- E-prints Service \\
- Manuscript Podcast for convenient understanding \\
- Global attainment for your research \\
- Manuscript accessibility in different formats \\
( Pdf, E-pub, Full Text, Audio) \\
- Unceasing customer service \\
Track the below URL for one-step submission \\
https://juniperpublishers.com/online-submission.php \\
\hline
\end{tabular}

